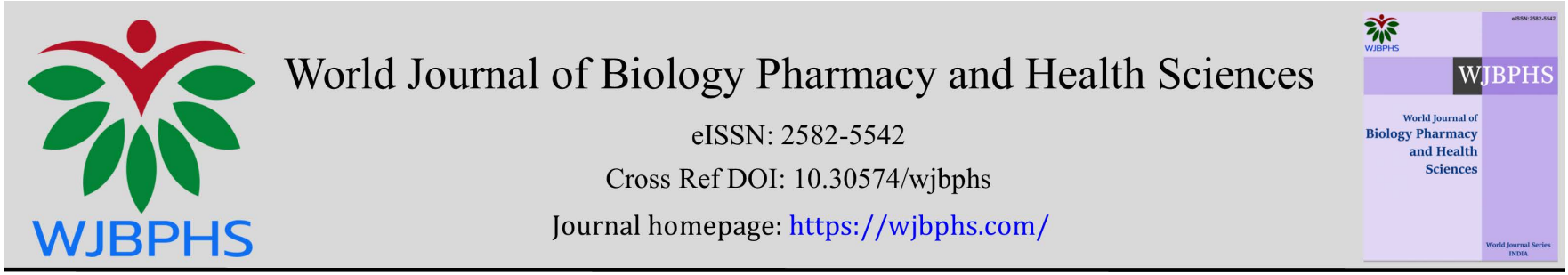

(RESEARCH ARTiCLE)

\title{
Age, seasons and influence of body mass index on menarche among secondary school girls in Port Harcourt, Nigeria
}

\author{
Loveday Ese Oghenemavwe, Michael Omonkheoa Oyakhire and Chidubem Oraelosi * \\ Department of Anatomy, College of Health Sciences, University of Port Harcourt, Rivers State, Nigeria.
}

World Journal of Biology Pharmacy and Health Sciences, 2021, 08(03), 005-012

Publication history: Received on 02 November 2021; revised on 06 December 2021; accepted on 08 December 2021

Article DOI: https://doi.org/10.30574/wjbphs.2021.8.3.0124

\begin{abstract}
Menarche is a significant marker of maturity and puberty in girls, and it is a transition influenced by different biophysical factors. This study was carried out to determine the age, seasons and the influence of body mass index (BMI) on menarche. A total of 450 girls' between the ages of 10 and 19 years participated in the study. Age at menarche was obtained via the recall quo cross sectional method. Parameters measured were; standing height (SH), weight (Wt) and BMI. A total of $373(82.9 \%)$ girls had their menarche in their early adolescence while 77 girls $(17.1 \%)$ had their menarche in mid adolescence. Mean age at menarche was $13.17 \pm 1.48$ years. The average value for BMI was $20.35 \pm$ $3.77 \mathrm{~kg} / \mathrm{m} 2$, SH was $161.09 \pm 6.16 \mathrm{~cm}$, Wt was $52.53 \pm 9.21 \mathrm{~kg}$. Overweight girls were observed to attain menarche earlier, followed by those whose mean weight was in the normal range .Subjects in the underweight category had higher age at menarche. Menarche was high in the months of August, July and January. Menarche occurs early among secondary school girls in Port Harcourt and among other factors, those associated with BMI and stress are important in the onset of the biological event.
\end{abstract}

Keywords: Menarche; Puberty; Adolescence; Seasons; body mass index

\section{Introduction}

Menarche marks a lifetime event, characterized by the first menstrual flow [1]. It is seen in female humans at the onset of puberty. Adadevoh et al. [2] described it as the time in the life of an individual when she becomes fully equipped and ready for procreation; characterized by the appearance of secondary sexual features. In other words, puberty involves the physical changes which the body of a child undergoes to become an adult, capable of sexual reproduction. In females, such changes include the development of the nipple, growth of pubic and armpit hair with menarche as the hallmark of internal organ advancement $[3,4,5,6,7]$

Menarche is the third in the cascade of events by which puberty is characterized. The first sign of puberty is breast budding known as thelarche, which begins with the appearance of a firm, tender lump under the center of the areola of one or both breasts. This is followed by the appearance of pubic hair known as pubarche which usually begin with the appearance of hairs at the armpits. Then comes menarche, which is third in the events of puberty; a major indicator of female sexual and reproductive maturity. $[8,9]$ In the sequence and timing of events, it usually takes place within 2 to 3 years after thelarche. However, unlike other pubertal changes that are gradual and continuous, menarche is a unique event, often with a sudden onset. It is highly correlated with other pubertal characteristics and is therefore preferred as a benchmark for sexual maturation.

Several studies and reports have shown that the age at menarche is population specific $[10.11,12]$. In one study, the age at menarche (in years) was 9.1 to 17.7 with a median of 12.8 in the United States[10.11] A number of factors have

\footnotetext{
* Corresponding author: Chidubem Oraelosi

Department of Anatomy, College of Health Sciences, University of Port Harcourt, Rivers State, Nigeria.. 
been observed to impact the onset of menarche; including childhood obesity, [13], nutrition [14], socio-economic status $[15,16]$, environmental conditions [17], genetic factors [18] and certain disorders of neuro-endocrine origin. [4, 19]. Some certain measurement indicators of body size, such as weight, height and BMI are well correlated with menarche age. [20] Weight gain is said to become critical at the onset of menarche. [21] Also, early menarche has been associated with increased subcutaneous fat levels and BMI.[13] Most studies on menarcheal age in Nigeria considered BMI as the major biophysical determinant. [22, 23,24]

In recent times, the interplay of seasons and menarche has become a subject of interest, due to the influence of environmental factors on biological systems. Jee et al. [25] observed that certain seasons in the year favour menarche as more cases are recorded in the winter compared to Monsoon season. Menarche increases in Bangladesh population in January and December but reduces in August and September. There is however dearth of studies on the seasonality of menarche among Nigerian population. This study therefore aims to investigate seasonality of menarche and the influence of B.M.I among adolescent school girls in Rivers State, South-South-Nigeria.

\section{Material and methods}

It was a school-based descriptive cross-sectional status quo study among selected secondary schools in Rivers state, conducted over a ten month period between January and October, 2016. A total of one hundred and forty secondary school girls between the ages of 10-19 were recruited for the study. Nine secondary schools were selected by nonprobability convenience sampling method subject to limitations imposed by the dangerous security situation in the country. The inclusion criteria included female students who had attained menarche within the recent 12 months and were in good physical and mental health, with no evidence of chronic health conditions. Female students who were yet to attain menarche or who may have attained menarche for over 12 months and those with medical conditions that can affect their biophysical features such as tuberculosis, thyroid disorders, sickle cell anaemia, were excluded from the study. Written informed consent was given by participants after the procedure for the study was explained to them. In addition, ethical approval was granted by Ethics review committee of University of Port Harcourt, Port Harcourt, Nigeria. Also, questionnaires were used to obtain relevant data from subjects who met the eligibility criteria. Menarcheal age was assessed using the "status quo" method. Heights of subjects were measured using a portable standiometer (Pyrochy®) with subjects barefooted. Body weight was determined using the digital weighing scale (Omron Body Composition Monitor BF511) accurate to $0.1 \mathrm{~kg}$, adjusted to the Zero mark on a flat surface. The subjects were asked to step on it barefooted and without thick clothing and stockings. The body mass index was estimated by the Body composition analyser (OMRON $®$ BF 500Series) after the subject's height had been captured to ensure validity of data, all measurements were taken three times and the average recorded.

Data were analyzed with Excel toolpak Windows 10. Observations were categorized by age at menarche into three groups namely; early menarche, mid menarche and late menarche. Pearson's correlation test was used to correlate menarcheal age and anthropometric variables. T-test was used to compare group means with $\mathrm{P}<0.05$ taken as level of significance.

\section{Results}

Results are as presented in Tables 1 to 5. Table 1 shows age distribution of school girls at menarche, Descriptive statistics are presented in Table 2. Descriptive statistics as well as the Independent sample T-test comparing the two groups in Table 3. Frequency distribution of the month of menarche and the influence of BMI is as shown in Tables 4 and 5.

Table 1 Age distribution of adolescent school girls at menarche

\begin{tabular}{|l|l|c|c|l|l|}
\hline Parameters & N & Min & Max & Mean & S.D \\
\hline Age at menarche (month) & 450 & 107 & 204 & 157.47 & 17.67 \\
\hline Age in years (years) & 450 & 10 & 17 & 13.17 & 1.48 \\
\hline
\end{tabular}


Table 2 Descriptive statistics of the measured variables

\begin{tabular}{|l|l|l|l|l|l|}
\hline Parameters & N & Min & Max & Mean & S.D \\
\hline Height $(\mathrm{cm})$ & 450 & 144.00 & 182.00 & 161.09 & 6.16 \\
\hline Weight $(\mathrm{kg})$ & 450 & 36.20 & 95.90 & 52.53 & 9.21 \\
\hline BMI $\left(\mathrm{Kg} / \mathrm{m}^{2}\right)$ & 450 & 14.80 & 49.20 & 20.35 & 3.77 \\
\hline
\end{tabular}

$\mathrm{N}=$ amount, S.D=Standard Deviation, Min=Minimum, Max=Maximum

Table 3 Anthropometry at various menarche category

\begin{tabular}{|c|c|c|c|c|c|c|c|c|}
\hline \multirow[t]{2}{*}{ Parameters } & \multirow{2}{*}{$\begin{array}{l}\text { Menarche } \\
\text { category }\end{array}$} & \multirow[t]{2}{*}{$\mathbf{N}$} & \multirow[t]{2}{*}{ Min } & \multirow[t]{2}{*}{$\operatorname{Max}$} & \multirow[t]{2}{*}{ Mean } & \multirow[t]{2}{*}{ S.D } & \multicolumn{2}{|l|}{ T-test } \\
\hline & & & & & & & T-value & P-value \\
\hline \multirow[t]{2}{*}{ Height(standing) $(\mathrm{cm})$} & Early (10 - 14) & 373 & 144.00 & 182.00 & 161.07 & 6.28 & \multirow[t]{2}{*}{0.02} & \multirow{2}{*}{$\begin{array}{l}0.88 \\
\text { (NS) }\end{array}$} \\
\hline & Mid (15 - 17) & 77 & 147.50 & 177.00 & 161.19 & 5.54 & & \\
\hline \multirow[t]{2}{*}{ Weight(kg) } & Early (10 - 14) & 373 & 36.20 & 95.90 & 52.60 & 9.35 & \multirow[t]{2}{*}{0.13} & \multirow{2}{*}{$\begin{array}{l}0.72 \\
\text { (NS) }\end{array}$} \\
\hline & Mid (15 - 17) & 77 & 38.20 & 87.40 & 52.19 & 8.55 & & \\
\hline \multirow{2}{*}{$\operatorname{BMI}\left(\mathrm{Kg} / \mathrm{m}^{2}\right)$} & Early (10 - 14) & 373 & 14.80 & 49.20 & 20.42 & 3.90 & \multirow[t]{2}{*}{0.59} & \multirow{2}{*}{$\begin{array}{l}0.44 \\
\text { (NS) }\end{array}$} \\
\hline & Mid (15 - 17) & 77 & 15.90 & 31.00 & 20.05 & 3.08 & & \\
\hline
\end{tabular}

$\mathrm{N}=$ amount, $\mathrm{S} . \mathrm{D}=$ Standard Deviation, Min=Minimum, Max=Maximum, $\mathrm{S}=$ Significant, NS=Not Significant

Table 4 Frequency distribution of months of menarche

\begin{tabular}{|l|c|c|}
\hline \multicolumn{1}{l}{ Month of menarche } & Frequency & Percentage (\%) \\
\hline January & 53 & 11.78 \\
\hline February & 21 & 4.67 \\
\hline March & 28 & 6.22 \\
\hline April & 45 & 10.00 \\
\hline May & 32 & 7.11 \\
\hline June & 37 & 8.22 \\
\hline July & 45 & 10.00 \\
\hline August & 66 & 14.67 \\
\hline September & 53 & 11.78 \\
\hline October & 15 & 3.33 \\
\hline November & 25 & 5.56 \\
\hline December & 30 & 6.66 \\
\hline Total & 450 & 100 \\
\hline
\end{tabular}


World Journal of Biology Pharmacy and Health Sciences, 2021, 08(03), 005-012

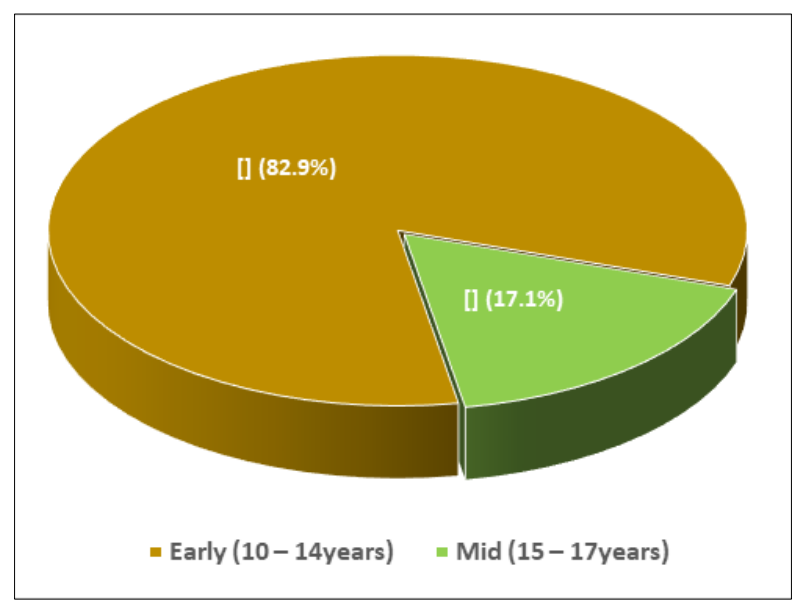

Figure 1 Pie chart showing distribution of adolescence age at menarche

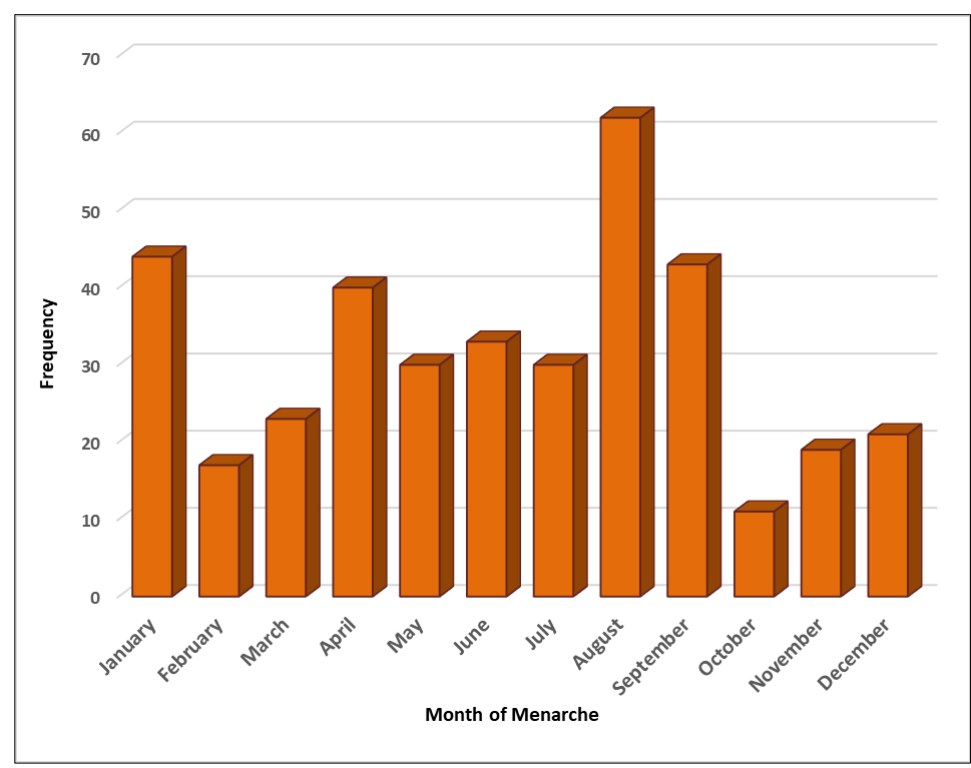

Figure 2 Frequency distribution of months of menarche for early menarche (10 - 14years)

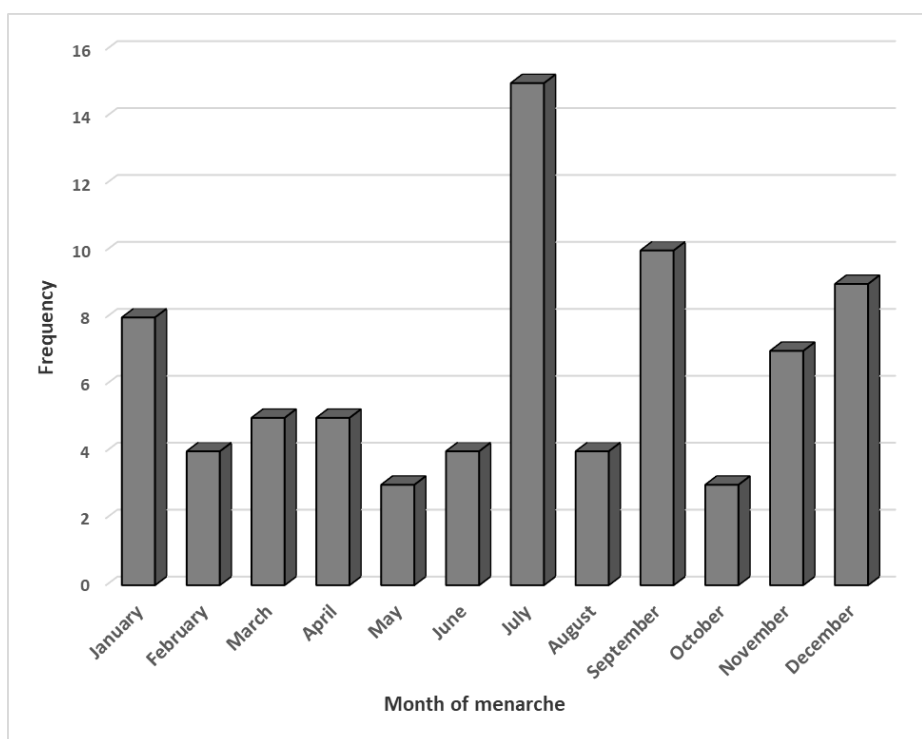

Figure 3 Distribution of months of menarche for the mid menarche (15 - 17years) 
Table 5 The role of BMI in menarche

\begin{tabular}{|l|c|c|c|}
\hline \multirow{2}{*}{ Age at menarche } & Early Menarche & Mid Menarche & Total \\
\cline { 2 - 4 } & $\mathbf{N}$ & $\mathbf{N}$ & $\mathbf{N}$ \\
\hline Underweight $(<18.5 \mathrm{~kg} / \mathrm{m} 2)$ & 72 & 18 & 90 \\
\hline Normal weight $(18.5-24.9 \mathrm{~kg} / \mathrm{m} 2)$ & 267 & 52 & 319 \\
\hline Overweight $(>25)$ & 34 & 7 & 41 \\
\hline Total & 373 & 77 & 450 \\
\hline
\end{tabular}

S.D = Standard Deviation, $\mathrm{N}=$ Number of subjects

\section{Discussions}

The appearance of menarche is an important event in the reproductive life of a woman as it is a major determinant of the capacity to reproduce. $[26,27]$ The mean menarcheal age of school girls in Port Harcourt was in the category of early menarche (10-14 years); about $82.7 \%$ of the sampled population had attained menarche at the age of 14 . This is similar to the findings of Nwakwo et al. [28]. The population size within early menarche category obtained in this study was higher than those from an earlier study by Adeshina and Peterside [24] with samples drawn from the same population. The difference may be attributed to improved standard of living. Also, we found in this study, average age of menarche higher than those reported for girls from France (12.5) [29], Kuwait (11.6 \pm 3.6$)$ [30] and Bangladesh (12.4 \pm 1.0$)$ [31]. Race, food preferences, geographical location are some factors that may be responsible for the observed difference.

Generally, it has been observed that age at menarche has decreased considerably in the past hundred years. The subjective reasons attributed for this decline include improvement in diet and economic status; health conditions and the influence of environmental conditions on female sexual maturity. A survey by Anderson et al. [32] showed the average age of menarche of girls in the United States dropped from 12.74 to 12.54 over a period of 25 years and American blacks had lower menarche age compared to whites. Among the Igbos of Ebonyi State in Eastern Nigeria, women with low education and socioeconomic status had menarche age of $15 . \pm 2.0$ compared to their counterpart who are educated $[33,34]$ The mean menarche age for European girls is reported to be 12.6 years for Italy and Greece and 15.2 years for Russia, 13.8 for Eskimos, 12.7 years for Asians. [35] The physiological implications of early and late menarche are well documented. Some studies suggest that late menarche affect fecundity, fertility and delay in ovulatory cycle [36]. Our result is similar to those reported by Sulayman et al.[37], as none of the volunteers in our study had their menarche after age 17.

Mean BMI (20.35 $\left.\pm 3.77 \mathrm{~kg} / \mathrm{m}^{2}\right)$ ), height $(161.09 \pm 6.16 \mathrm{~cm}$.) and weight $(52.53 \pm 9.21 \mathrm{~kg})$ in the current study are similar to those of Chukwujekwu et al. [38] The height is however higher than those reported by Adesina and Peterside [24] and Nwankwo et al. [28] in similar population. The minimum menarcheal weight was $36.20 \mathrm{~kg}$, and $26.2 \%$ of volunteers had their weight below 48kg proposed as critical body weight for menarche.

We observed that 77 girls were underweight, 267 were of normal weight, while 34 girls were overweight. The overweight girls attained menarche early, followed by normal and the underweight girls had a longer menarcheal age. The categorization of the volunteers into early and mid menarcheal classes, revealed similar patterns but the slight difference was that in mid menarche, the normal and overweight girls attained menarche early and almost at the same time while the underweight girls attained menarche late. This is in line with the findings of Frisch and Revelle, [21] who reported that heavier girls do appear to attain menarche much earlier, compared to lighter ones. He further postulated that accumulation of body fat up to a minimum of $17 \%$ of body weight is necessary for the onset of menarche in girls.

The volunteers studied attained menarche mostly in August (66 persons, 14.7\%), September (53 persons, 11.8\%) and January (52 persons, 11.6\%) while onset of menarche least occurred in October (14 persons, 3.1\%) as shown in Table 4. Among Indians, menarche occurred with two monthly peaks of frequency in July-September and in DecemberJanuary. [39]. An important contributing factor to the occurrence of menarche seen in this study may be due to reduction in stress levels and physical activity. Students are always on holiday in Port Harcourt between July - August and December and are therefore free from stress associated with school activities. A less-stressful atmosphere during school holiday has been postulated to trigger the onset of menarche by influencing the hypothalamus and the hypothalamohypophyseal gonadal axis $[40,41,42]$ 


\section{Conclusion}

The mean age at menarche among Port Harcourt secondary school girls is 13.7. A higher proportion of participants are in the category of early menarche. None of the participantts was in the group of late menarche. BMI was observed to positively influence the age of menarche; girls with higher BMI tend to achieve menarche quite early. The less stressful seasons of the year are most favourable for menarche.

\section{Compliance with ethical standards}

\section{Acknowledgments}

The authors wish to acknowledge the principal and staff of the following schools: Federal Government College, Port Harcourt, University of Port Harcourt Demonstration Secondary School, Aluu, Olobo Premier College, Choba, Community Secondary School, Ogale, Federal Government Girls College, Abuloma, Birabi Memorial Grammar School, Bori, Abonnema Girls Secondary School, Abonnema, Federal Science and Technical College, Ahoada and Mac Master Comprehensive Academy, Akinima; for their support and the enabling environment they provided for the success of this work.

\section{Disclosure of conflict of interest}

The Authors declare they had no conflicts of interest in this research.

\section{Statement of informed consent}

All participants were adequately informed about details of the study. They signed the consent form voluntarily.

\section{References}

[1] Bhalla M. Age of menarche - a review. Indian journal of pediatrics. 1975; 42(6): 166-175.

[2] Adadevoh SWK, Agble TK, Hobbs C. Elkins TE. Menarcheal age in Ghanaian school girls. International Journal of Gynecology \& Obstetrics. 1989; 30(1): 63-68.

[3] Marti-Henneberg C, Vizmanos B. The duration of puberty in girls is related to the timing of its onset. J Pediatr.1997; 131: 618-621.

[4] Kaplowitz PB, Slora EJ, Wasserman RC, Pedlow SE, Herman-Giddens ME. Earlier onset of puberty in girls: Relation to increased body mass index and race. Pediatrics. 2001; 108: 347-53.

[5] Biro FM, McMahon RP, Striegel-Moore R, Crawford P, Obarzanek E, Barton BA, Falkner F. Impact of timing of pubertal maturation on growth in black and white female adolescents the NHLBI Growth and Health Study. J Pediatr. 2001; 138: 636-643.

[6] Kaplowitz P. Pubertal development in girls: Secular trends. Curr Opin Obstet Gynecol. 2006; 18: 487-91

[7] Biro FM, Huang B, Crawford PB, Lucky AW, Striegel-Moore R, Barton BA, Daniels S. Pubertal correlates in black and white girls. J Pediatr. 2006; 148: 234-240.

[8] Berenbaum SA, Beltz AM, Corley R. Chapter Two-The Importance of Puberty for Adolescent Development: Conceptualization and Measurement. Advances in child development and behavior. 2015; 48: 53-92.

[9] Razzaghy-Azar M, Moghimi A, Sadigh N, Montazer M, Golnari P, Zahedi-Shoolami L, Fereshtehnejad SM. Age of puberty in Iranian girls living in Tehran. Annals of human biology. 2006; 33 (5-6): 628-633.

[10] Anderson SE, Must A. Interpreting the continued decline in the average age at menarche: results from two nationally representative surveys of US girls studied 10 years apart. The Journal of pediatrics. 2005; 147(6): 753760 .

[11] Cabrera SM, Bright GM, Frane JW, Blethen SL, Lee, PA. Age of thelarche and menarche in contemporary US females: a cross-sectional analysis. Journal of Pediatric Endocrinology and Metabolism. 2014; 27(1-2), 47-51.

[12] Olotu EJ, Oladipo GS. Age decline in the onset of menarche in Southern Nigerian population Global J. Med. 2006; 5(2): 89-91 
[13] Freedman DS, Khan LK, Serdula MK, Dietz WH, Srinivasan SR, Berenson GS. The relation of menarcheal age to obesity in childhood and adulthood: the Bogalusa heart study. BMC pediatrics. 2003; 3(1): 3.

[14] Mounir GM, El-Sayed NA, Mahdy NH, Khamis SE. Nutritional factors affecting the menarcheal state of adolescent school girls in Alexandria. J Egypt Public Health Assoc. 2007: 82(3-4): 239-60.

[15] Oduntan SO, Ayeni O, Kale 00. The age of menarche in Nigerian girls. Annals of Human Biology. 1976; 3(3): 269274.

[16] Wronka I, Pawlinska-Chmara R. Menarcheal age and socioeconomic factors in Poland. Ann Hum Biol. 2005; 32: 630-638.

[17] Ameade EPK, Garti HA. Age at Menarche and Factors that Influence It: A Study among Female University Students in Tamale, Northern Ghana. PloS one. 2016; 11(5): e0155310.

[18] Towne B, Czerwinski SA, Demerath EW, Blangero J, Roche AF, Siervogel RM. Heritability of age at menarche in girls from the Fels Longitudinal Study. Am J Phys Anthropol. 2005; 128: 210-219.

[19] Parent AS, Teilmann GJ, Juul A, Skakkebaekn NE, Toppari J, Bourguignon JP. The timing of normal puberty and the age limits of sexual precocity: variations around the world, secular trends, and changes after migration. Endocr Rev. 2003; 24: 668-693.

[20] Karapanou 0, Papadimitriou A. Determinants of menarche. Reprod Biol Endocrinol. 2010; 8: 115.

[21] Frisch RE, Revelle R. Height and weight at menarche and a hypothesis of critical body weights and adolescent events. Science. 1970; 169: 397-399.

[22] Tunau KA, Adamu AN, Hassan MA, Ahmed Y, Ekele BA. Age at menarche among school girls in Sokoto, Northern Nigeria. Annals of African Medicine. 2012; 11(2): 103-107.

[23] Okagua J, Okagua K. Menarcheal age and nutrition status among school girls' in Port Harcourt Southern Nigeria. Tropical Journal of Obstetrics and Gynaecology. 2015; 32(2): 146-151.

[24] Adesina AF, Peterside O. Age at menarche and body mass index among adolescent secondary school girls in Port Harcourt. Nigeria. J. Denta. Med Res. 2013; 3(5): 41-46.

[25] Jee HR, Abu AS, Ummeh TA, Alain BL, Mahbubur R, Parul C. Age of Onset, nutritional determinants, and seasonal variations in menarche in rural Bangladesh. Journal of Health Population amd Nutrition. 2009; 27(6): 802-807.

[26] Scholl TO, Chen X. Puberty and Adolescent. In Goldman MB, Troisi R, Rexrose Kathryn (Eds) Women and Health, $2^{\text {nd }}$ edition. 2013; 151-162).

[27] Jones RE, Lopez KH. Human Reproduction. 4th edition. 2014; 103-118.

[28] Nwankwo M, Danborno B, Hamman WO. Relationship between age at menarche and anthropometric profiles, demography, and ethnicity among adolescent girls in Nigeria. Annals of Bioanthropology. 2016; 4(1): 1.

[29] Lalys L, Pineau JC. Age at menarche in a group of French schoolgirls, Pediatr. Int. 2014; 56(4): 601-604.

[30] Al-Awhadi N, Al-Kandari N, Al-Hasan T, Almurjan D, Ali S, Al-Taiar A. Age at menarche and Its relationship to body mass index among adolescent girls in Kuwait. 2013; 13: 29.

[31] Islam MS, Hussain MA, Islam S, Mahumud RA, Biswas T, Islam SMS. Age at menarche and its socioeconomic determinants among female students in an urban in Bangladesh. Sexual \& Reproduction healthcare. 2017; 12: 88-92.

[32] Anderson SE, Dallai GE, Must A. Relative weight and race influence average age at menarche: Results from two nationally representative surveys of US girls studied 25 years apart. Pediatrics. 2003; 111: 844-50.

[33] Umeora O, Egwuatu V. Age at menarche and the menstrual pattern of Igbo women of South East Nigeria. Afr J Reprod Hlth. 2008; 12(1): 90 - 95.

[34] Abikwe CC, Mamah JE, Okorochukwu BC, Nnadozie CU, Obarezi CH, Ekwedigwe KC, Age at menarche, menstrual characteristics, and it associated morbidities among secondary school students in Abakaliki. Hellyon. 2020; 6: 16.

[35] Flaws JA, Sharara FI, Silbergeld EL, Hirshfield AN. Environmental exposures and women reproductive health. In Goldman MB, Hatch SC (eds) Women and Health. Academic press. 2000; 625-633. 
[36] Guldbrandsen K, Hakonsen LB, Toft G, Lyngso J, Olsen J, Ranlau-Hansen CH. Age of menarche and time of pregnancy. Human Rproduction. 2014; 29(9): 2058-2064.

[37] Sulayman U, Ameh N, Addesiyim AG, Ojabo AO, Ozed-William, Avidime S. Age at menarche and prevalence OF menstrual abnormalities among adolescent in Zaria, Northern Nigeria Ann Niger. Med. 2013; 7(2): 66-70.

[38] Chukwujekwu IE, Ezejindu DN, Olabisi O. Age, wight, body mass index and waist circumference at menarche among school girls in Otolo, Nnewi, South East Nigeria. International Journal of Research. 2014; 1(4): $116-122$.

[39] De Sanctis, V, Bernasconi S, BianchinL, Bona G, Bozzola M, Buzi F, De Sanctis C, Rigon F, Tatò L, Tonini G, Perissinotto E. Onset of menstrual cycle and menses features among secondary school girls in Italy: A questionnaire study on 3,783 students. Indian journal of endocrinology and metabolism. 2014; 18(1): S84.

[40] Matchock RL, Susman EJ, Brown FM. Seasonal rhythms of menarche in the United States: correlates to menarcheal age, birth age, and birth month. Womens Health Issues. 2004; 14: 184-92.

[41] Gueresi P. Monthly distribution of menarche in three provinces of north Italy. Ann Hum Biol. 1997; 24: 157-68.

[42] Park SH, Shim YK, Kim HS, Eun BL. Age and seasonal distribution of menarche in Korean girls. J Adolesc Health. 1999; 25: 97. 